\title{
Screening of BRCA1/2 genes mutations and copy number variations in patients with high risk for hereditary breast and ovarian cancer syndrome (HBOC)
}

Fatima Zahra El Ansari ${ }^{1,2^{*}}$, Farah Jouali ${ }^{2}$, Nabila Marchoudi ${ }^{2}$, Mohcine Mechita Bennani ${ }^{1}$, Naima Nourouti Ghailani ${ }^{1}$, Amina Barakat ${ }^{1}$ and Jamal Fekkak ${ }^{2}$

\begin{abstract}
Background: Hereditary breast and ovarian cancer (HBOC) is an autosomal dominant inherited cancer susceptibility disorder. Both BRCA1 and BRCA2 genes are considered as high penetrance genes of this syndrome. The identification of $B R C A 1 / 2$ genetic alterations before cancer development, grant patients the chance to benefit from various medical cancer prevention approaches. Therefore, the appearance of recent advanced technologies in molecular analysis such as next generation sequencing has simplified full BRCA1/2 analysis.

Many attempts took place in hope of understanding the molecular germline spectrum of these two genes in Moroccan HBOC patients. However, most of the past projects focused only on young breast cancer cases, lacked ovarian cancer cases in their cohort and only a limited number of these studies were able to analyze the entire exons or copy number variations for both genes.

In attempt of gaining more information regarding the molecular profile of BRCA1/2 in $\mathrm{HBOC}$, we conducted a study in which we analyze their molecular profile on selected Moroccan patients suspected of having HBOC syndrome.
\end{abstract}

Methods: In this study we obtained blood samples from 64 selected Moroccan patients, who suffered from Breast and/or ovarian cancer and had a strong family history for cancer. To analyze BRCA1/2 punctual variants and copy number variations, we used the lon Personal Genome Machine (PGM) and Oncomine BRCA1/2 research assay panel. Afterward, we correlated the molecular results with the clinic-pathologic data using IBM SPSS Statistics ver 2.

(Continued on next page)

\footnotetext{
* Correspondence: fzelansari1993@gmail.com

'Biomedical Genomics and Oncogenetics Research Laboratory, Faculty of Sciences and Techniques of Tangier, University Abdelmalek Essaâdi, 90000 Tangier, Morocco

${ }^{2}$ Molecular Biology Department, ANOUAL Laboratory, Casablanca, Morocco
}

(C) The Author(s). 2020 Open Access This article is licensed under a Creative Commons Attribution 4.0 International License, which permits use, sharing, adaptation, distribution and reproduction in any medium or format, as long as you give appropriate credit to the original author(s) and the source, provide a link to the Creative Commons licence, and indicate if changes were made. The images or other third party material in this article are included in the article's Creative Commons licence, unless indicated otherwise in a credit line to the material. If material is not included in the article's Creative Commons licence and your intended use is not permitted by statutory regulation or exceeds the permitted use, you will need to obtain permission directly from the copyright holder. To view a copy of this licence, visit http://creativecommons.org/licenses/by/4.0/ The Creative Commons Public Domain Dedication waiver (http://creativecommons.org/publicdomain/zero/1.0/) applies to the data made available in this article, unless otherwise stated in a credit line to the data. 
(Continued from previous page)

Results: From the 64 selected cases, Forty-six had breast cancer, fifteen had ovarian cancer and three had both breast and ovarian cancer. The molecular analysis revealed that 18 patients from the 64 harbored a pathogenic variant (28\%). Twelve had six different BRCA1 pathogenic variants and six had six different BRCA2 pathogenic variants. In this study, we report four pathogenic variants that to the best of our knowledge has never been reported in the Moroccan population before. Regarding copy number variation analysis, No CNV was detected in both genes for all the 64 successfully sequenced and analyzed patients in our cohort.

Conclusion: Work like the present has an important implication on public health and science. It is critical that molecular profiling studies are performed on underserved and understudied population like Morocco.

Keywords: Hereditary breast and ovarian cancer, BRCA1, BRCA 2

\section{Background}

Hereditary breast and ovarian cancer (HBOC), is an autosomal dominant inherited cancer susceptibility disorder [1], account for $5-7 \%$ of all breast cancer cases [2], and $10-15 \%$ of all ovarian cancer cases [3]. The diagnosis of this syndrome has been entrenched in 1970 [4, 5], since then the scientific world has been conducting many studies in hope of defining the clinical characteristics of this syndrome, and understanding its genetic origins.

Until date, the national comprehensive cancer network $(\mathrm{NCCN})$ has established clinical guidelines that help in distinguishing $\mathrm{HBOC}$ patients from other sporadic cases [6]. Moreover, genetic studies have demonstrated that $\mathrm{HBOC}$ is a highly heterogeneous disease, associated with germline genetic alterations in a number of genes such as BRCA1, BRCA2, TP53, PTEN, ATM, NBS1, RAD50, BRIP1 and PALB2 [7]. With BRCA1 and BRCA2 as main predisposing genes of HBOC. Hence, BRCA1 and BRCA2 carriers present a risk of $65-80 \%$ and $45-85 \%$ for developing breast cancer while, for ovarian cancer they present a risk of $37-62 \%$ and $11-23 \%$ respectively [8].

The identification of BRCA1/2 genes pathogenic alterations in patients suspected to have HBOC, before cancer development or in the first stages of breast and ovarian cancer, grants them the chance to benefit from various medical cancer prevention approaches, such as risk-reducing surgery (mastectomy and salpingooophorectomy), chemo-prevention and enhanced surveillance approaches [9]. Therefore, BRCA1/2 genetic analysis has become a fundamental concern of doctors and families with a high risk of HBOC syndrome.

Since the beginning of molecular analysis till date, $B R C A 1 / 2$ genetic screening has been massively facilitated by the appearance of recent advanced technologies. This advancement has aid enormously in the characterization and the identification of both genes genetic alterations. So far globally, a total of 1826 pathogenic $B R C A$ variant has been reported [10]. Other genetic alterations such as large exon, gene deletions/duplication have also been reported in HBOC families with a significant proportion [11].
Although there are similarities among BRCA1/2 testing criteria worldwide, several reports had shown that different populations have variable $B R C A 1$ and $B R C A 2$ mutation spectrum and prevalence [12-14]. Therefore, it is only reasonable to hypothesize that the spectrum and the prevalence of pathogenic variants will differ in Morocco as well. Accordingly, different molecular studies of BRCA1/2 have been conducted in hope of understanding their molecular germline alterations in Moroccan HBOC patients. Most of these studies have focused only on breast cancer cases and on young patients due to the fact that breast cancer is described as young women disease in the Arab world and other developing nations like some African and Asian countries [15-17]. Moreover, studies that analyzed the molecular profile of BRCA1/2 in HBOC Moroccan patients rarely had ovarian cancer cases in their cohort. Finally, a limited number of Moroccan studies were able to analyze the entire exons or copy number variations for both genes [18-20].

In attempt of filling some gaps and gaining more information regarding the molecular germline profile of $B R C A 1 / 2$ in Moroccan HBOC and around the globe. We initiated a study in which we analyze the punctual variants and copy number variations of both genes on selected HBOC Moroccan patients. To achieve our goal, we used next generation sequencing technology and the commercially available Oncomine $B R C A 1 / 2$ research assay panel. This panel analyze both punctual variants and large exons deletions and duplications. Afterward, we correlated the molecular results with the clinicopathological data of the patients, in hope of understanding more the implication of these molecular alterations in HBOC syndrome.

\section{Methods}

\section{Study population}

A total of 64 female at-risk for $\mathrm{HBOC}$ were enrolled in this study between 2016 and 2020. The study material has been collected from individuals referred to ANOUAL laboratory for $B R C A 1 / 2$ genetic testing. Even though all cases were recruited from the same city, they 
had different ethnicity. However, only 23 from the 64 gave their origins the others gave their living location Therefore; this parameter was not included in this study.

All the cases recruited had to fulfill the National Comprehensive Cancer Network (NCCN) selection criteria. HBOC was suspected in cases with breast and/or ovarian cancer, and a personal or a family history of any of the followings:

(a) Breast cancer diagnosed at or before the age of 45 years,

(b) Ovarian cancer diagnosed at or before the age of 45 years,

(c) Multiple primary breast cancers either in one or both breasts,

(d) triple-negative breast cancer diagnosed before the age of 60 years,

(e) Two or more relatives with breast or ovarian cancer, with at least one under the age of 50 years;

(f) Three or more relatives with breast or ovarian cancer at any age.

Prior to the collection of blood samples and clinical data from all participants. Written informed consents were signed from them and their relatives that were recruited in this study. All included Siblings in this study were considered as one case. A pre-analysis genetic counseling was accomplished with patients to collect their family and tumor information. This project was approved by the local Ethics in Research Committee.

\section{DNA isolation}

Peripheral blood samples from the patients were collected in EDTA tubes. Genomic DNA was extracted automatically from blood samples using Maxwell $^{\circ} 16$ Blood DNA Purification Kit and stored at $-20^{\circ} \mathrm{C}$. DNA purity and concentration was measured by Nano Drop 2000 Spectrophotometer and Qubit 3.0 (Thermo Fisher Scientific, Waltham, USA).

\section{Next generation sequencing}

$B R C A 1$ and BRCA2 genes were screened using the Ion PGM sequencing platform and Oncomine BRCA1/2 Research Assay panel, this panel contains 265 primer pairs in two pools, covering all coding sequences of both genes, including all splice sites with an average of $64 \mathrm{bp}$ extensions from the intron junctions. The sequencing was carried out in three steps: library preparation, template preparation and finally templates sequencing.

Libraries were generated according to the manufacturer's instructions guidelines. Briefly, we used $10 \mathrm{ng}$ of DNA isolated from whole blood to generate the sequencing libraries by amplification reaction for each pool. After target amplification, pool 1 and pool 2 amplification reactions were combined into one PCR tube. Followed by partial digestion of primers using FuPa enzyme, and barcode adapter's ligation. Finally, generated amplicons were purified using AMPure $^{\mathrm{Tn}}$ XP Reagent. Barcoded purified libraries were quantified and diluted to $100 \mathrm{pM}$ before template preparation.

Sequencing templates were produced by clonal amplification of the libraries using the Ion OneTouch 2 System and Ion Torrent PGM Hi-Q VIEW OT2 Kit (Thermo Fisher Scientific, Waltham, MA, USA). The Template-positive Ion SphereTM Particles were isolated with MyOne Streptavidin C1 Beads (Thermo Fisher Scientific, Waltham, MA, USA), and washed with Ion OneTouch Wash Solution, Using the Ion OneTouch ES system (Thermo Fisher Scientific, Waltham, MA, USA). Finally, the barcoded and enriched templates were loaded on the Ion Torrent 316 V2 sequencing chip for deep sequencing on the personal genome machine (PGM) using Ion PGM Hi-Q view Sequencing Solutions kit, all according to the manufacturer's protocol.

\section{Data analysis}

Generated raw data sequences quality assessment and alignment to the hg19 human reference genome, was carried out by Ion Torrent Suite software (version 5.0.5; Thermo Fisher Scientific). Coverage analysis and Single nucleotide variant calling were performed using Torrent coverage and Variant Caller plug-in (version 5; Thermo Fisher Scientific).

Generated BAM files were used for the annotation of single nucleotide variants, insertions, deletions and copy number variants in the Ion Reporter Server System (Thermo Fisher Scientific) according to the original algorithm pipeline developed by Thermo Fisher Scientific for BRCA1/2 Research Assay Panel. Only single nucleotide variants with a coverage superior to $250 \mathrm{X}$ were considered authentic.

\section{Genetic variant classification}

Genetic variants were classified according to the guidelines of the American College of Medical Genetics and Genomics (ACMG) using a five-tier system: pathogenic, likely pathogenic, variant of unknown significance (VUS), likely benign, or benign [21].

Variants including nonsense, missense, frameshift, large genomic rearrangements, and splice site, were considered as pathogenic when resulting in a prematurely truncated protein and/or reported in BIC or Clinvar as pathogenic. If not their pathogenicity is predicted by in silico analysis via: Sift, Polyphen, Mutation taster and identified through a literature search.

\section{Statistical analysis}

Statistical analysis to assess the association between clinic-pathologic data and BRCA1/2 punctual variants 
status was carried out with IBM Statistical Package for Social Science (SPSS) version 20. Chi-square $\left(x^{2}\right)$ test and Fisher's exact test both were applied to obtain the $P$-value. Correlations was defined as $P<0.05$.

\section{Results}

\section{Clinical features of the cohort}

From the 64 collected cases, Forty six females had breast cancer fifteen females had ovarian cancer and three had both breast and ovarian cancer. Therefore, in our cohort we have 49 breast tumors and 18 ovarian tumor.

The median age of all the recruited patients in our cohort was 42, ranging from 23 to 55 years old. The majority of our BC tumors had Ductal carcinoma (91\%), T2 tumor size (44.8\%), SBR grade II (46.9\%), and luminal subtype of cancer (59\%). All the clinico-pathological data of breast cancer cases are summarized in Table 1. Regarding ovarian cancer cases, the majority had serous carcinoma (66.67\%), T3 tumor size (61.11\%) and SBR grade III (55.56\%). All the clinico-pathological data of ovarian cancer cases are listed in Table 2.

\section{Pathogenic variants identified in $B R C A 1$ and $B R C A 2$}

After performing $B R C A 1 / 2$ molecular analysis, we detected 12 pathogenic variants in 18 patients from 64 (28.\%). 12 patients harbored $B R C A 1$ variant, and 6 harbored $B R C A 2$ variant.

In $B R C A 1$ gene we detected 6 different pathogenic variants and in BRCA2 gene we detected 6 different pathogenic variants as well. All the pathogenic variants found in our study are reported in Table 3. All these variants were stated in both BIC and Clinvar.

From the 18 patients with pathogenic variants in $B R A C 1 / 2$ genes in our study; twelve had breast cancer, five had ovarian cancer and one had both breast and ovarian cancer. The breast data of the last mentioned patient were included in Table 1 and her ovarian data were included in Table 2.

\section{Variants of uncertain significance in BRCA1 and $B R C A 2$}

From all the 64 successfully sequenced patients we found one uncertain significance variant in one ovarian cancer patient and her sister that suffered from breast cancer. This variant was not found in their healthy third sister. The variant c.91 T > G (p.Trp31Gly) is a substitution of the nucleotide thymine with guanine in exon 3 of $B R C A 2$ gene, causing the substitution of Tryptophan to glycine in the binding region of $B R C A 2$ gene. This variant was included in the statistical analysis between BRCA carriers and no carriers in Table 2. No likely pathogenic variant was detected in our population.

\section{Copy number variations}

No CNV was detected in both genes for all the 64 successfully sequenced and analyzed patients in our cohort.

\section{Discussion}

To date, there have been several attempts to describe the spectrum of $B R C A 1 / 2$ germline pathogenic variants in Moroccan patients with HBOC syndrome. However, past works have failed to depict a comprehensive

Table 1 Correlation of the clinical characteristics with mutation status in Breast cancer cases

\begin{tabular}{llll}
\hline clinical characteristics & Total & BRCA1/2 Carriers & non Carriers \\
\hline Histological type & & $12(92.3)$ & $33(91.6)$ \\
ductal carcinoma & $45(91.8 \%)$ & $1(7.6)$ & $2(5.5)$ \\
lobular carcinoma & $3(6.1 \%)$ & 0 & $1(2.7)$ \\
Others & $1(2.04 \%)$ & & \\
Tumor size & & $3(23.0 \%)$ & $11(30.5 \%)$ \\
T1 & $14(28.5 \%)$ & $5(38.4 \%)$ & $17(47.2 \%)$ \\
T2 & $22(44.8 \%)$ & $4(30.7 \%)$ & $7(19.4 \%)$ \\
T3 & $11(22.4 \%)$ & $1(7.6 \%)$ & $1(2.7 \%)$ \\
T4 & $2(4.08 \%)$ & & 0.7 \\
SBR grade & & $2(15.3 \%)$ & $4(11.1 \%)$ \\
I & $6(12.2 \%)$ & $6(46.1 \%)$ & $17(47.2 \%)$ \\
II & $23(46.9 \%)$ & $5(38.4 \%)$ & $15(41.6 \%)$ \\
III & $20(40.8 \%)$ & & 0.9 \\
Molecular type & & $8(61.5 \%)$ & $9(25.0)$ \\
triple negative & $17(34.6 \%)$ & $5(38.4 \%)$ & $24(66.6)$ \\
luminal & $29(59 \%)$ & $0(0 \%)$ & $3(8.3)$ \\
HER2+ & $3(6.1 \%)$ & & 0.03 \\
\hline
\end{tabular}


Table 2 Correlation of the clinical characteristics with mutation status in ovarian cancer

\begin{tabular}{llll}
\hline clinical characteristics & Total & BRCA carriers & BRCA non carriers \\
\hline Histological type & & & \\
Serous & $12(66.67 \%)$ & $4(71.42 \%)$ & $7(63.64 \%)$ \\
$\quad$ Other & $6(33.33 \%)$ & $2(28.57 \%)$ & $4(36.36 \%)$ \\
Tumor size & & & \\
T3 & $11(61.11 \%)$ & $4(71.42 \%)$ & $7(54.54 \%)$ \\
T4 & $7(38.89 \%)$ & $2(28.57 \%)$ & $5(45.45 \%)$ \\
SBR grade & & & \\
II & $8(44.44 \%)$ & $4(57.14 \%)$ & $4(36.36 \%)$ \\
III & $10(55.56 \%)$ & $2(42.86 \%)$ & $8(63.64 \%)$ \\
\hline
\end{tabular}

picture; they either focused only on young patients with breast cancer, lacked ovarian cancer cases in their cohort, or only sequenced selected regions of both genes. Moreover, no Moroccan study has analyzed copy number variations for both genes in patients suspected for HBOC before. Thus, to overcome past limitations, the goal of our study is to describe the punctual variants and copy number variations profile of $B R C A 1$ and
BRCA2 genes on Moroccan patients with breast and/or ovarian cancer suspected to have HBOC syndrome.

Respecting the National Comprehensive Cancer Network (NCCN) criteria for HBOC syndrome, we were able to recruit 64 patients suspected of HBOC syndrome; Forty-six (71.9\%) had breast cancer, fifteen (23.4\%) had ovarian cancer and three (4.7\%) had both breast and ovarian cancer. The predominance of breast

Table 3 Detected BRCA1/2 pathogenic variants

\begin{tabular}{|c|c|c|c|c|c|c|c|c|}
\hline Gene & DNA level (Protein level) & NM & Families & Exon & $\begin{array}{l}\text { Variant } \\
\text { type }\end{array}$ & $\begin{array}{l}\text { Molecular } \\
\text { consequence }\end{array}$ & Protein consequence & $\begin{array}{l}\text { Variant } \\
\text { coverage }\end{array}$ \\
\hline \multirow[t]{12}{*}{ BRCA1 } & \multirow[t]{3}{*}{ c.798_799delTT (p.Ser267fs) } & \multirow[t]{3}{*}{3} & \multirow[t]{3}{*}{$||,,||||}$, & \multirow[t]{3}{*}{11} & \multirow[t]{3}{*}{ Deletion } & \multirow[t]{3}{*}{ frameshift } & \multirow{3}{*}{$\begin{array}{l}\text { Premature stop codon at } \\
\text { p.Ser267Lysfs*19 }\end{array}$} & 834 \\
\hline & & & & & & & & 1007 \\
\hline & & & & & & & & 768 \\
\hline & \multirow[t]{4}{*}{ c.3279delC (P.Tyr1094fs) } & \multirow[t]{4}{*}{4} & \multirow[t]{4}{*}{$\mathrm{IV}, \mathrm{V}, \mathrm{VI}$} & \multirow[t]{4}{*}{11} & \multirow[t]{4}{*}{ Deletion } & \multirow[t]{4}{*}{ framshift } & \multirow{4}{*}{$\begin{array}{l}\text { Premature stop codon at } \\
\text { p.Tyr1094llefs*15 }\end{array}$} & 531 \\
\hline & & & & & & & & 468 \\
\hline & & & & & & & & 679 \\
\hline & & & & & & & & 788 \\
\hline & c.4823C > G (p.Ser1608Ter) & 1 & VII & 16 & SNV & nonsense & $\begin{array}{l}\text { Premature stop codon atp. } \\
\text { Ser1608Ter }\end{array}$ & 1340 \\
\hline & c.1016dupA (p.Val340fs) & 1 & VIII & 10 & duplication & frameshift & $\begin{array}{l}\text { Premature stop codon atp. } \\
\text { Val340Glyfs* } 6\end{array}$ & 543 \\
\hline & \multirow[t]{2}{*}{ c.66_67delAG (p.Glu23fs) } & \multirow[t]{2}{*}{2} & \multirow[t]{2}{*}{$I X, X$} & \multirow[t]{2}{*}{2} & \multirow[t]{2}{*}{ Deletion } & \multirow[t]{2}{*}{ frameshift } & \multirow{2}{*}{$\begin{array}{l}\text { Premature stop codon atp. } \\
\text { Glu23fs*17 }\end{array}$} & 634 \\
\hline & & & & & & & & 957 \\
\hline & c.5158C > T (p.Arg1720Trp) & 1 & $X I$ & 18 & SNV & missense & $\begin{array}{l}\text { Premature stop codon atp. } \\
\text { Arg1720Trp }\end{array}$ & 729 \\
\hline \multirow[t]{6}{*}{ BRCA2 } & $\begin{array}{l}\text { c.1302_1305delAAGA } \\
\text { (p.Lys437fs) }\end{array}$ & 1 & $X \|$ & 10 & Deletion & frameshift & $\begin{array}{l}\text { Premature stop codon atp. } \\
\text { Lys } 437 f f^{*} 22\end{array}$ & 934 \\
\hline & c.7110delA (p.Lys2370fs) & 1 & XIII & 14 & Deletion & frameshift & $\begin{array}{l}\text { Premature stop codon atp. } \\
\text { Lys } 2370 \mathrm{fs}^{*}\end{array}$ & 1021 \\
\hline & $\begin{array}{l}\text { c.3847_3848delGT } \\
\text { (p.Val1283fs) }\end{array}$ & 1 & XIV & 11 & Deletion & frameshift & $\begin{array}{l}\text { Premature stop codon } \\
\text { atP.Val1283fs*2 }\end{array}$ & 670 \\
\hline & $\begin{array}{l}\text { c.5576-5579delTTAA } \\
\text { (p.l1859fs) }\end{array}$ & 1 & $X V$ & 11 & Deletion & frameshift & Premature stop codon atp. $11859 f^{*} 3$ & 534 \\
\hline & $\begin{array}{l}\text { c.7235_7236insG } \\
\text { (p.Lys2413fs) }\end{array}$ & 1 & $X \mathrm{Vl}$ & 14 & insertion & frameshift & $\begin{array}{l}\text { Premature stop codon atp. } \\
\text { Lys } 2413 \mathrm{fs}^{*}\end{array}$ & 760 \\
\hline & c.3860delA (p.Asn1287fs) & 1 & $\mathrm{XVII}$ & & Deletion & frameshift & $\begin{array}{l}\text { Premature stop codon atp. } \\
\text { Asn } 1287 \mathrm{fs}^{*} 6\end{array}$ & 1167 \\
\hline
\end{tabular}


cancer cases in $\mathrm{HBOC}$ cohort is reported in all $\mathrm{HBOC}$ studies worldwide [22, 23]. Epidemiological studies in Morocco have shown that the frequency of breast cancer is higher than ovarian cancer, which increases the probability for the predominance of breast cancer patients in our cohort [19, 24, 25].

In agreement with other studies, the median age of all the 64 analyzed patients in our cohort is 42 years old. For breast cancer cases, alone the median age is 42 years old, and for ovarian cancer cases alone the median age is 43 years old. To the best of our knowledge, no Moroccan study has worked on HBOC cohort with ovarian cancer cases before. Therefore, we are only able to compare our breast cancer cases median age with the one reported by Tazzite et al. [26] and Laraqui et al. [19]. Our findings correlate with both studies that reported a median age inferior to 45 years old for familial breast cancer cases. On the other hand, our entire HBOC cohort median age line up with that reported by Ciernikova et al. [22] and Alemar et al. [23]. However, our cohort median age is still younger than the one reported by Tingyan Shi et al. [27]. Many studies have indicated that the median age of onset in north African countries including Morocco is more than 10 years younger than the age of onset in European/North American countries [15, 26].

Clinico-pathological data of all patients included in this study, were collected through a review of the patients medical records. The majority of our BC cases had Ductal carcinoma (91\%), T2 tumor size (44.8\%), SBR grade II (46.9\%), and luminal subtype of cancer (59\%). These results correlate with other local and international studies [28-30]. Besides, according to Tazzite et al. [26] and Musolino et al. [31], these characteristics are also the most encountered in sporadic breast cancer cases. Apropos ovarian cancer cases, the majority had Serous carcinoma (66.67\%), T3 tumor size (61.11\%), and III SBR grade (55.56\%). We didn't find any Moroccan study concerning ovarian cancer clinico-pathological data. However, Our findings line up with other studies on other populations [32, 33].

In this study, the molecular analysis was performed using the Oncomine BRCA1/2 Research Assay Panel that could detect both punctual variants and copy number variations. It is considered as an alternative assay to investigate both types of $B R C A 1 / 2$ genetic alterations in one workflow. This panel efficiency has been investigated by Hirotsu et al. (2017) [34], and according to his study results, the Oncomine $B R C A 1 / 2$ research assay panel is a highly accurate tool for analyzing variants with wide-ranging allelic fractions and for detecting copy number alterations.

To the best of our knowledge, this is the first Moroccan study to analyze $B R C A 1 / 2$ copy number variations in Morocco. Globally, only a limited number of studies analyzed $B R C A 1 / 2 \mathrm{CNV}$ profile in $\mathrm{HBOC}$ patients. From a population to another the results are still contradicted $[35,36]$, which emphasize the importance of more studies to build solid conclusions regarding the implication of $B R C A 1 / 2 \mathrm{CNV}$ in HBOC.

After molecular analyses of $B R C A 1 / 2$ genes, eighteen patients (28.1\%) in our cohort from the 64 harbored $B R C A 1 / 2$ pathogenic alteration. In $B R C A 1$ gene we found 6 different pathogenic variants in 12 patients (66\%). while for BRCA2 gene we found 6 different pathogenic variants in 6 patients (33\%) and one variant of uncertain significance. No copy number variation was detected in both genes for all the successfully sequenced 64 patients. All the pathogenic variants detected in our study and their molecular effect are summarized in Table 3 and are mentioned in both data bases BIC and Clinvar. The prevalence of $B R C A 1 / 2$ pathogenic variants that we found in this study line up with that reported by Laraqui et al. [37], Jouali et al. [38] and Alemar et al. [23]. However, this prevalence is still higher than that reported by Tazzite et al. [18]. This variability in pathogenic punctual variants percentage could be explained by the fallowed selection criteria and the technology used in these studies. In our cohort, we found a dominance of $B R C A 1$ gene pathogenic variants compared to $B R C A 2$ pathogenic variants these results correlate with other studies [23, 37].

Regarding BRCA1 gene we found 6 different pathogenic variants. The first is c.798_799delTT (p.Ser267fs), it was detected in three unrelated patients. All three had breast cancer from which two had triple negative subtype and one had luminal subtype. This variant has been reported in different Moroccan studies [38, 39] and also was reported in some Tunisian and Algerian studies, to be the first non-Jewish founder $B R C A 1$ pathogenic variant in north Africa [37].

Another four patients harbored the variant c.3279delC (P.Tyr1094fs), two were discovered to be second degree relatives from the mother side after investigation. Both cousins had luminal breast cancer. As for the third patient, she suffered from aggressive triple negative breast cancer and ovarian cancer. Finally, the last patient suffered from triple negative breast cancer. This variant was first reported in 2005 by van der Hout et al. [40] in Netherlands, then it was reported for the first time in morocco at 2012 by Tazzite et al. [18], afterward it was reported by El khachibi et al. [41] and in 2015 it was reported by Strom et al. [42] in the USA. The high prevalence of this variant in our cohort and the fact that it has been reported several times in morocco state the probability of it being a founder mutation of our population or maybe for a specific ethnicity in morocco. However, none of the four patients provided their origins and we were unable to contact them. 
The third variant C.4823C > G (p.Ser1608Ter) was detected in one patient and her sister. Both came for $B R C A 1 / 2$ testing after one was diagnosed with triple negative breast cancer and the other had ovarian cancer. As far as we know, this variant has been reported in USA and UK by Strom CM et al. [42] and Robertson L et al. [43], and this is the first study to report this pathogenic variant in Morocco.

The fourth BRCA1 pathogenic variant c.1016dupA (p.Val340fs) was detected in a patient suffering from luminal breast cancer. This pathogenic variant is reported as the 12th most common frameshift variant occurring in $B R C A 1$ gene. It was detected in different populations [42, 44-46] and once in Morocco by Laraqui et al. [8].

The fifth BRCA1 pathogenic variant is c.66_67delAG (p.Glu23fs), it was detected in two patients one with triple negative breast cancer and the second with ovarian cancer. It is also known as 187delAG, this variant is one of three main pathogenic founder variants in the Ashkenazi Jewish population [47]. In Morocco, this variant has been reported by Zoure et al. [48] and Jouali et al. [38] and globally, it has been found in different populations [49-51].

The last BRCA1 pathogenic variant we found in this study is c.5158C $>\mathrm{T}$ (p.Arg1720Trp), it was detected in a patient with ovarian cancer. This variant has been reported in Morocco by Laraqui et al. [8], in Finland by Kuusisto et al. [52] and in Italy by Antonucci et al. [53].

Apropos $B R C A 2$ gene, we identified 6 different pathogenic variants in 6 unrelated patients and one variant of uncertain significance in one patient and her sister. The first patient had ovarian cancer and harbored c.1302_1305delAAGA (p.Lys437fs) pathogenic variant. This variant was identified in morocco by Laarabi et al. [39] and it was reported in several populations around the world $[54,55]$.

The second patient had triple negative breast cancer and harbored c.7110delA (p.Lys2370fs) pathogenic variant. This variant was reported for the first time by Tazzite et al. [18] and our study is the second in the world to report this variant.

The third patient also had triple negative breast cancer and harbored the pathogenic variant C.3847delG (P.Val1283fs). as far as we know, this is the first Moroccan study to report this variant. Nevertheless, it was reported in different populations worldwide [56-58].

The fourth pathogenic variant C.5576-5579delTTAA (P.I1859fs) was detected in a patient with luminal breast cancer. According to our literature search, this is the first study to report this variant in Morocco, but it has been reported in other studies $[59,60]$.

Our fifth BRCA2 pathogenic variant is c.7235 7236insG (p.Lys2413fs) it was detected in a patient with ovarian cancer. This variant has been reported for the first time by Tazzite et al. [18] and our study is the second to report it.
Our last BRCA2 pathogenic variant is c.3860delA (p.Asn1287fs). It was detected in a patient suffering from ovarian cancer. To the best of our knowledge, this is the first Moroccan study to report this variant however, it was reported in different populations worldwide [61, 62].

Finally, in our study we reported one variant of uncertain significance c. $91 \mathrm{~T}>\mathrm{G}$ (p.Trp31Gly) in BRCA2 gene. This variant was found in our patient and in one of her two sisters as well. Both sisters carrying the variant suffered from cancer while their third sister who didn't harbor the variant was healthy. This variant was reported by Laura Caleca et al. [63]. In her study, Caleca proved that this variant affects the binding of BRCA2 protein with the PALB2 protein.

Comparing our BRCA1/2 identified pathogenic variants with all the pathogenic variants found by other Moroccan studies (Table 4). We detected In BRCA2 gene, two variants that have been reported only in this study and by Tazzite et al. [18]. The variant c.7235_7236insG (p.Lys2413Terfs) and the variant c.7110del (p.Lys2370fs). The fact that these variants were never reported in other studies worldwide, rise the probability of them being specific pathogenic variants for the Moroccan population. Furthermore, we found four pathogenic variants that have never been reported in other Moroccan studies. The first C.4760C > G (p.S1587Ter) was found in a patient that confirmed her Moroccan Arab origins. The second C.3847delG (P.Val1283fs) was found in a patient that confirmed her Moroccan Amazigh origins. While the third C.5576-5579delTTAA (P.I1859fs9) and the fourth c.3860delA (p.Asn1287fs) were found in patients with European ancestors. However, all four mutations were reported in European studies. We believe that the history of the migration flow between the two populations can explain the origins of these pathogenic variants.

In our study, we didn't report any copy number variation in both genes. All our patients were successfully sequenced and according to the Ion reporter pipeline, the $\mathrm{CNV}$ analysis was successful for all the patients in our cohort. Copy number variation in both genes was reported by Wen-Ming Cao et al. [35] with a percentage of $16.1 \%(5 / 31)$. While, other studies state that BRCA1/2 CNVs for HBOC patients is rarely found $[64,65]$. More global studies are required to define the implication of BRCA1/2 CNVs in HBOC.

After molecular analysis, we compared the histopathological characteristics between $B R C A 1 / 2$ pathogenic mutations carriers and no carriers for breast and ovarian cancer cases separately. For both cancers, no significant difference was found concerning Histological type, Tumor size, and SBR grade. While, for the molecular subtype of breast cancer we found a correlation between $B R C A 1 / 2$ carriers and triple negative breast cancer with a $P$-Value $<0.05$. Our results correlate with those of 
Table 4 BRCA1/2 reported pathogenic variants in the Moroccan population

\begin{tabular}{|c|c|c|c|c|c|}
\hline \multirow[t]{2}{*}{ Study } & \multirow{2}{*}{$\begin{array}{l}\text { Number } \\
\text { of cases }\end{array}$} & \multicolumn{3}{|c|}{ Reported variants } & \multirow[t]{2}{*}{ Methodology } \\
\hline & & $\begin{array}{l}\text { Genetic } \\
\text { variant }\end{array}$ & Consequence & Gene & \\
\hline \multirow{9}{*}{$\begin{array}{l}\text { Tazzite et al. [18] } \\
\text { (Morocco) }\end{array}$} & \multirow[t]{9}{*}{40} & c.5558dup & p.Tyr1853Ter & BRCA1 & \multirow[t]{9}{*}{ Full BRCA1/BRCA2 screening using Sanger } \\
\hline & & c.798799delTT & p.Ser267LysfsX1 & BRCA1 & \\
\hline & & c.2805delA & p.S896Vfs 104 & BRCA1 & \\
\hline & & c.3279delC & p.lle1859LysfsX3 & BRCA1 & \\
\hline & & $\begin{array}{l}\text { c.5062 } \\
\text { 5064delGTT }\end{array}$ & p.Val1688del & BRCA1 & \\
\hline & & c.3381delT & p.Phe1127LeufsX & BRCA2 & \\
\hline & & c.7110delA & p.Lys2370fs & BRCA2 & \\
\hline & & c.7235insG & p.Thr2412fsX2 & BRCA2 & \\
\hline & & c.7110delA & Lys2370fs & BRCA2 & \\
\hline \multirow{4}{*}{$\begin{array}{l}\text { Laraqui et al. [9] } \\
\text { (Morocco) }\end{array}$} & \multirow[t]{4}{*}{121} & c.798799delTT & p.Ser267LysfsX1 & BRCA1 & \multirow{4}{*}{ Full BRCA1 gene sequencing using Sanger } \\
\hline & & c.1016dupA & p.Lys1698X & BRCA1 & \\
\hline & & C. $4942 \mathrm{~A}>\mathrm{T}$ & p.Lys1648X & BRCA1 & \\
\hline & & c. $5095 C>T$ & p.Arg1699Trp & BRCA1 & \\
\hline \multirow{3}{*}{$\begin{array}{l}\text { Laarabi et al. [39] } \\
\text { (Morocco) }\end{array}$} & \multirow[t]{3}{*}{74} & c.68_69delAG & p.Glu23fs X17 & \multirow{3}{*}{$\begin{array}{l}\text { BRCA1 } \\
\text { BRCA2 }\end{array}$} & \multirow{3}{*}{$\begin{array}{l}51 \text { underwent sanger sequencing for exon } 10 \text { of BRCA2 gene. Full } \\
\text { BRCA1/2 sequencing for } 23\end{array}$} \\
\hline & & c.5073dupA & p.Trp1692Metfs & & \\
\hline & & $\begin{array}{l}\text { c.1310 } \\
\text { 1313delAAGA }\end{array}$ & p.Lys437|lefsX22 & & \\
\hline \multirow{4}{*}{$\begin{array}{l}\text { Jouali et al. [38] } \\
\text { (Morocco) }\end{array}$} & \multirow[t]{4}{*}{15} & c.2126insA & p.Phe709TyrfsX3 & BRCA1 & \multirow[t]{4}{*}{ Full BRCA1/BRCA2 screening using next generation sequencing } \\
\hline & & $\begin{array}{l}\text { c.7234__ } \\
\text { 7235insG }\end{array}$ & p.Thr2412Serfs & BRCA2 & \\
\hline & & c.3453delT & & BRCA1 & \\
\hline & & $\begin{array}{l}\text { c.1310 } \\
\text { 1313delAAGA }\end{array}$ & p.Lys437llefsX22 & BRCA2 & \\
\hline \multirow[t]{12}{*}{ Our study } & \multirow[t]{12}{*}{64} & $\begin{array}{l}\text { c.798_ } \\
\text { 799delTT }\end{array}$ & p.Ser267LysfsX19 & BRCA1 & \multirow{12}{*}{$\begin{array}{l}\text { Full BRCA1/BRCA2 punctual variants and copy number variations } \\
\text { screening using next generation sequencing }\end{array}$} \\
\hline & & c.3279delC & p.Tyr1094llefsX15 & BRCA1 & \\
\hline & & c. $4823 C>G$ & p.Ser1608Ter & BRCA1 & \\
\hline & & c.1016dupA & p.Val340GlyfsX6 & BRCA1 & \\
\hline & & c.66_67delAG & p.Glu23fsX17 & BRCA1 & \\
\hline & & c. $5158 \mathrm{C}>\mathrm{T}$ & p.Arg1720TrpX & BRCA1 & \\
\hline & & $\begin{array}{l}\text { c.1302_ } \\
\text { 1305delAAGA }\end{array}$ & p.Lys437fsX22 & BRCA2 & \\
\hline & & c.7110delA & p.Lys2370fsX & BRCA2 & \\
\hline & & $\begin{array}{l}\text { c.3847- } \\
\text { 3848delGT }\end{array}$ & P.Val1283fsX2 & BRCA2 & \\
\hline & & $\begin{array}{l}\text { c.5576- } \\
\text { 5579delTTAA }\end{array}$ & p.11859fsX3 & BRCA2 & \\
\hline & & $\begin{array}{l}\text { c.7235_- } \\
\text { 7236insG }\end{array}$ & p.Lys2413fsX & BRCA2 & \\
\hline & & c.3860delA & p.Asn $1287 \mathrm{fs} \times 6$ & BRCA2 & \\
\hline
\end{tabular}

Alemar et al. [23], Cao et al. [66]. Moreover, according to different epidemic molecular studies, BRCA1 mutation carriers have more chances of developing triple negative breast cancer subtype [67-69].
In our cohort 46 patients $(34 \mathrm{BC}, 10 \mathrm{OC}$ and $2 \mathrm{BC}+$ $\mathrm{OV})$ didn't harbor any $B R C A 1 / 2$ pathogenic variant or copy number variation, despite having a strong family history for cancer. These results drive us to suspect that 
these patients may harbor genetic alterations in other genes implicated in HBOC syndrome such as TP53, PTEN, ATM, NBS1, RAD50, BRIP1 and PALB2, which emphasize the need for analyzing all the genes implicated in $\mathrm{HBOC}$ in one workflow instead of only $B R C A 1 / 2$.

\section{Conclusion}

Works like the present have an important implications in both public health and science. First, proper risk assessment including genetic testing of high risk individuals can lead to increased awareness of cancer risk and effective use of interventions to reduce $B R C A$-related cancer incidence and mortality. Second, understanding the spectrum of ethnic-specific mutation landscape can lead to genetic tests tailored to ethnic groups, which can increase sensitivity and specificity of analytic techniques as well as lowering the cost. Lastly, genetic testing can indicate presence or absence of $B R C A$ mutation as well as variants of uncertain clinical significance (VUS). As catalogue of genetic variants are collected, further refinement is possible to decipher the mechanistic meaning of the VUSs. To achieve a comprehensive collection of all variants worldwide, it is critical that molecular profiling studies are performed on underserved and understudied population such as Morocco. Thus, despite the lack of novelty in our study, we believe that the clinical, economic, and scientific implication of our results is broad and profound.

\begin{abstract}
Abbreviations
HBOC: Hereditary breast and ovarian cancer; BC: Breast cancer; OV: Ovarian cancer; NCCN: National comprehensive cancer network; CNV: Copy number variation; VUS: Variant of uncertain significant
\end{abstract}

\section{Acknowledgments}

We thank Anoual laboratory Casablanca and Biomedical Genomics and Oncogenetics Research Laboratory at Sciences and Techniques Faculty of Tangier for their support.

\section{Authors' contributions}

FE contributed for the study conception, design, writing of the manuscript, acquisition of data and analysis. FJ participated to the design of the study and helped with data analysis. NM contributed in the study conception and helped with data and analysis. BM, GN, and $A B$ contributed to the design of the study and interpretation of the data, JF contributed to the design of the study, data interpretation and approved the analyzed literature data, all authors read and approved the final manuscript.

\section{Funding}

The authors have no support or funding to report.

\section{Availability of data and materials}

The datasets analyzed during the current study and a list of material requirement will be available from the corresponding author on reasonable request.

\section{Ethics approval and consent to participate}

The study was approved by the Ethics Committee for Research of the University Hassan II. All participants gave a written informed consent to participate in the study.
Consent for publication

Not applicable.

\section{Competing interests}

The authors declare that they have no competing interests.

Received: 2 March 2020 Accepted: 3 August 2020

Published online: 10 August 2020

\section{References}

1. Lux MP, Fasching PA, Beckmann MW. Hereditary breast and ovarian cancer: review and future perspectives. J Mol Med. 2006;84:16-28.

2. Larsen MJ, Thomassen M, Gerdes AM, Kruse TA. Hereditary breast cancer: clinical, pathological and molecular characteristics. Breast Cancer (Auckl). 2014:8:145-55.

3. Toss A, Tomasello C, Razzaboni E, Contu G, Grandi G, Cagnacci A, Schilder RJ, Cortesi L. Hereditary ovarian cancer: Not only BRCA 1 and 2 Genes. Biomed Res Int. 2015;2015:341723.

4. Lynch HT, Krush AJ. Carcinoma of the breast and ovary in three families. Surg Gynecol Obstet. 1971;133(4):644-8.

5. Lynch HT, Krush AJ, Lemon HM, Kaplan AR, Condit PT, Bottomley RH. Tumor variation in families with breast cancer. JAMA. 1972;222(13):1631-5.

6. NCCN. Clinical practice guidelines in oncology (NCCN guidelines) genetic/ familial high-risk assessment: breast and ovarian. ed 4 ed; 2013. National Comprehensive Cancer Network.

7. Lynch HT, Snyder C, Casey MJ. Hereditary ovarian and breast cancer: what have we learned?. Ann Oncol. 2013;24(Suppl 8):viii83-95.

8. Laraqui A, Uhrhammer N, Lahlou-Amine I, Rhaffouli HE, Baghdadi JE, Dehayni $M$, et al. Mutation screening of the BRCA1 gene in early onset and familial breast/ovarian Cancer in Moroccan population. Int J Med Sci. 2013; 10(1):60-7.

9. Padamsee TJ, Wills CE, Yee LD, Paskett ED. Decision making for breast cancer prevention among women at elevated risk. Breast Cancer Res. 2017: 19. https://doi.org/10.1186/s13058-017-0826-5.

10. Golubeva VA, Nepomuceno TC, Alvaro NA. Monteiro. Germline Missense Variants in BRCA1: New Trends and Challenges for Clinical Annotation. Cancers. 2019;11(4):522.

11. Puget N, Torchard D, Serova-Sinilnikova O, Lynch HT, Feunteun J, Lenoir GM, Mazoyer S. A 1 kb Alu-mediated germ-line deletion removing BRCA1 exon 17. Cancer Res. 1997;57:828-31.

12. Azzollini J, Scuvera G, Bruno E, Pasanisi P, Zaffaroni D, Calvello M, et al, Mutation detection rates associated with specific selection criteria for BRCA1/2 testing in 1854 high-risk families: a monocentric Italian study. Eur J Intern Med. 2016;32:65-71.

13. Felix GES, Zheng Y, Olopade OI. Mutations in Context: Implications of BRCA testing in diverse populations. Fam Cancer. 2018:17(4):471-83.

14. Cardoso FC, Goncalves S, Mele PG, Liria NC, Sganga L, Perez ID, Podesta EJ, Solano AR. BRCA1 and BRCA2 mutations and clinical interpretation in 398 ovarian cancer patients: comparison with breast cancer variants in a similar population. Hum Genomics. 2018;12:39.

15. Bakkach J, Mansouri M, Derkaoui T, Loudiyi A, Fihri M, Hassani S, et al. Clinicopathologic and prognostic features of breast cancer in young women: a series from North of Morocco. BMC Women's Health. 2017:106;29.

16. Bhikoo R, Srinivasa S, Yu T-C, Moss D, Hill AG. Systematic review of breast cancer biology in developing countries (part 2): Asian subcontinent and South East Asia. Cancers. 2011:3:2382-401.

17. Bhikoo R, Srinivasa S, Yu T-C, Moss D, Hill AG. Systematic review of breast cancer biology in developing countries (part 1): Africa, the Middle East, Eastern Europe, Mexico, the Caribbean and South America. Cancers. 2011;3: 2358-81.

18. Amal Tazzite A, Hassan Jouhadi B, Sellama Nadifi A, Aretini P, et al. BRCA1 and BRCA2 germline mutations in Moroccan breast/ovarian cancer families: Novel mutations and unclassified variants. Gynecol Oncol. 2012;125(3):68792125 (2012) 687-692.

19. Laraqui A, Uhrhammer N, Lahlou-Amine I, Rhaffouli HEL, El Baghdadi J, et al. Mutation Screening of the BRCA1 Gene in Early Onset and Familial Breast/ Ovarian Cancer in Moroccan Population. Int J Med Sci. 2013;10(1):60-7. .

20. Abdulrashid K, AlHussaini N, Ahmed W, Thalib L. Prevalence of BRCA mutations among hereditary breast and/or ovarian cancer patients in Arab countries: systematic review and meta-analysis. BMC Cancer. 2019;19:256. 
21. Walsh R, Mazzarotto F, Whiffin N, Buchan R, Midwinter W, Wilk A, Li N, Felkin L, Ingold N, Govind R, Ahmad M, Mazaika E, Allouba M, Zhang X, de Marvao A, Day SM, Ashley E, Colan SD, Michels M, Pereira AC, Jacoby D, Ho CY, Thomson KL, Watkins H, Barton PJR, Olivotto I, Cook SA, Ware JS. Quantitative approaches to variant classification increase the yield and precision of genetic testing in Mendelian diseases: the case of hypertrophic cardiomyopathy. Genome Med. 2019;11:5.

22. Ciernikova S, Tomka M, Kovac M, Stevurkova V, Zaja V. Age and geographical distribution in families with BRCA1/BRCA2 mutations in the Slovak Republic. Hered Cancer Clin Pract. 2006;4(1):7-11.

23. Alemar B, Gregorio C, Herzog J, Matzenbacher Bittar C, BrinckmannOliveira Netto C, Artigalas O, et al. BRCA1 and BRCA2 mutational profile and prevalence in hereditary breast and ovarian cancer ( $\mathrm{HBOC}$ ) probands from Southern Brazil: Are international testing criteria appropriate for this specific population. PLoS ONE. 2017;13(5).

24. Desmond A, Kurian AW, Gabree M, Mills MA, Anderson MJ, Kobayashi Y, Horick N, Yang S, Shannon KM, Tung N, Ford JM, Lincoln SE, Ellisen LW. Clinical Actionability of multigene panel testing for hereditary breast and ovarian Cancer risk assessment. JAMA Oncol. 2015;1(7):943-51.

25. Shulman LP. Hereditary Breast and Ovarian Cancer (HBOC): Clinical features and counseling for BRCA1 and BRCA2, Lynch syndrome, Cowden syndrome, and li-Fraumeni syndrome. Obstet Gynecol Clin North Am. 2010;37(1):109-33.

26. Tazzite A, Jouhadi H, Saiss K, Benider A, Nadifi S. Relationship between family history of breast Cancer and Clinicopathological features in Moroccan patients. EJHS. 2013;23:150-7.

27. Shi T, Pan W, Xie C, Yin S, Shi D, Wei C, Tang W, Jiang R, Cheng X, Wei Q, Wang Q, Zang R. BRCA1 and BRCA2 mutations in ovarian cancer patients from China: ethnic-related mutations in BRCA1 associated with an increased risk of ovarian cancer. Int J Cancer. 2017;140(9):2051-9.

28. Yang X, Wu J, Lu J, Liu G, Di G, Chen C, Hou Y, Sun M, Yang W, Xu X, et al. Identification of a comprehensive Spectrum of genetic factors for hereditary breast Cancer in a Chinese population by next-generation sequencing. PLoS One. 2015;10(4):e0125571.

29. Pathology of familial breast cancer: differences between breast cancers in carriers of BRCA1 or BRCA2 mutations and sporadic cases. Breast Cancer Linkage Consortium. Lancet. 1997;349(9064):1505-10.

30. El Saghir NS, Zgheib NK, Assi HA, Khoury KE, Bidet Y, Jaber SM, Charara RN, et al. BRCA1 and BRCA2 Mutations in Ethnic Lebanese ArabWomenWith High Hereditary Risk Breast Cancer. TheOncologist. 2015;20:357-64.

31. Musolino A, Michiara M, Bella MA, Naldi N, Zanelli P, Bortesi B, Capelletti M, Soldani L, Camisa R, Martella E, Franciosi V, Savi M, Neri TM, Ardizzoni A, Cascinu S. molecular profile and clinical variables in brca1-positive breast cancers. a population-based study. Tumori. 2005;91:505-12.

32. Fernandes GC, Michelli RAD, Galvão HCR, Paula AE, Pereira R, Andrade CE, Felicio PS, et al. Prevalence of BRCA1/BRCA2 mutations in a Brazilian population sample at-risk for hereditary breast cancer and characterization of its genetic ancestry. Oncotarget. 2016;7(49):80465-81.

33. Shi T, Wang P, Xie C, Yin S, Di Shi CW, Tang W, Jiang R, Chen X, Wei Q, Wang Q, Zang R. BRCA1 and BRCA2 mutations in ovarian cancer patients from China: ethnic-related mutations in BRCA1 associated with an increased risk of ovarian cancer. IJC. 2017;140:2051-9 V C 2017 UICC.

34. Hirotsu Y, Ooka Y, Sakamoto I. Hiroshi Nakagomi, and Masao Omata; simultaneous detection of genetic and copy number alterations in BRCA1/2 genes. Oncotarget. 2017;8(70):114463-73.

35. Cao W-M, Zheng Y-B, Gao Y, Ding X-W, Sun Y, Huang Y, Lou C-J, Pan Z-W, Peng $G$, Wang $X-J$. Comprehensive mutation detection of BRCA1/2 genes reveals large genomic rearrangements contribute to hereditary breast and ovarian cancer in Chinese women. BMC Cancer. 2019;19(1):551.

36. Walker LC, Marquart L, Pearson JF, Wiggins GAR, O'Mara TA, Parsons MT, BCFR DB, McGuffog L, Dennis J, Benitez J, Slavin TP, Radice P, Frost D, EMBRACE, Godwin AK, Meindl A, Schmutzler RK, Collaborators GEMOS, Isaacs C, Peshkin BN, Caldes T, Hogervorst FBL, HEBON, Lazaro C, Jakubowska A, Montagna M, KConFab Investigators, Chen X, Offit K, Hulick PJ, Andrulis IL, Lindblom A, Nussbaum RL, Nathanson KL, Chenevix-Trench G, Antoniou AC, Couch FJ, Spurdle AB. Evaluation of copy-number variants as modifiers of breast and ovarian cancer risk for BRCA1 pathogenic variant carriers. Eur J Hum Genet. 2017;25:432-8.

37. Abdelilah Laraqui, Nancy Uhrhammer, Hicham EL Rhaffouli, Yassine Sekhsokh, Idriss Lahlou-Amine, Tahar Bajjou, Farida Hilali, Jamila El Baghdadi; BRCA Genetic Screening in Middle Eastern and North African: Mutational Spectrum and Founder
BRCA1 Mutation (c.798_799delTT) in North African; Hindawi Publishing Corporation Disease Markers Volume 2015, Article ID 194293.

38. Jouali F, Ratbi I, Elalaoui SC, Fekkak, and Abdelaziz Sefiani. First application of next-generation sequencing in Moroccan breast/ovarian cancer families and report of a novel frameshift mutation of the BRCA1 gene. Oncol Lett. 2016;12(2):1192-6.

39. Laarabi FZ, Jaouad IC, Ouldim K, Aboussair N, Jalil A, Gueddari BE, Benjaafar N, Sefiani A. Genetic testing and first presymptomatic diagnosis in moroccan families at high risk for breast/ovarian cancer. Oncol Lett. 2011;2:389-93.

40. van der Hout AH, van den Ouweland AM, van der Luijt RB, Gille HJ, Bodmer $D$, Brüggenwirth $H$. Mulder IM, et al; a DGGE system for comprehensive mutation screening of BRCA1 and BRCA2: application in a Dutch cancer clinic setting. Hum Mutat. 2006;27(7):654-66.

41. El Khachibi M, Diakite B, Hamzi K, Badou A, Senhaji MA, Bakhchane A, Jouhadi H, Barakat A, Benider A. Nadifi S; screening of exon 11 of BRCA1 gene using the high resolution melting approach for diagnosis in Moroccan breast cancer patients. BMC Cancer. 2015;15:81.

42. Strom CM, Rivera S, Elzinga C, Angeloni T, Rosenthal SH, Goos-Root D, Siaw M, Platt J, Braastadt C, Cheng L, Ross D. Sun W; development and validation of a next-generation sequencing assay for BRCA1 and BRCA2 variants for the clinical laboratory. PLoS One. 2015;10(8):e0136419.

43. Robertson L, Hanson H, Seal S, Warren-Perry M, Hughes D, Howell I, Turnbull C, Houlston R, Shanley S, Butler S. D G Evans, G Ross, D Eccles, a Tutt, N Rahman, BRCA1 testing should be offered to individuals with triple-negative breast cancer diagnosed below 50 years. Br J Cancer. 2012;106(6):1234-8.

44. Simard J, Tonin P, Durocher F, Morgan K, Rommens J, Gingras S, Samson C, Leblanc JF, Bélanger C, Dion F, et al. Common origins of BRCA1 mutations in Canadian breast and ovarian cancer families. Nat Genet. 1994 Dec;8(4):392-8.

45. Janavičius R. Founder BRCA1/2 mutations in the Europe: implications for hereditary breast-ovarian cancer prevention and control. EPMA J. 2010;1(3): 397-412.

46. Foretova L, Machackova E, Navratilova M, Pavlu H, Hruba M, Lukesova M. Valik D; BRCA1 and BRCA2 mutations in women with familial or early-onset breast/ovarian cancer in the Czech Republic. Hum Mutat. 2004 Apr;23(4): 397-8.

47. Struewing JP, Brody LC, Erdos MR, et al. Detection of eight BRCA1 mutations in 10 breast/ovarian cancer families, including 1 family with male breast cancer. Am J Hum Genet. 1995;57(1):1-7.

48. Zoure AA, Slaoui M, Bambara HA, Sawadogo AY, Compaoré TR, Ouédraogo NLM, El Mzibri M, Attaleb M, Traoré SS, Simpore J, Bakri Y. BRCA1 c.68_ 69delAG (exon2), c.181T>G (exon5), c.798_799delTT and 943 ins10 (exon11) mutations in Burkina Faso. J Public Health Afr. 2018;9(1):663.

49. Fackenthal JD. Olopade Ol; breast cancer risk associated with BRCA1 and BRCA2 in diverse populations. Nat Rev Cancer. 2007;7(12):937-48.

50. Walsh T, Casadei S, Lee MK, Pennil CC, Nord AS, Thornton AM, Roeb W, Agnew KJ, Stray SM, Wickramanayake A, Norquist B, Pennington KP, Garcia RL, King M-C, Swisher EM. Mutations in 12 genes for inherited ovarian, fallopian tube, and peritoneal carcinoma identified by massively parallel sequencing. Proc Natl Acad Sci U S A. 2011;108(44):18032-7.

51. Gabaldó Barrios X, Sarabia Meseguer MD, Marín Vera M, Sánchez Bermúdez Al, Macías Cerrolaza JA, Sánchez Henarejos P, Zafra Poves M, García Hernández MR, Cuevas Tortosa E, Aliaga Baño Á. Castillo Guardiola V, et al; molecular characterization and clinical interpretation of BRCA1/BRCA2 variants in families from Murcia (South-Eastern Spain) with hereditary breast and ovarian cancer: clinical-pathological features in BRCA carriers and noncarriers. Familial Cancer. 2017;16(4):477-89.

52. Kuusisto KM, Bebel A, Vihinen M, Schleutker J, Sallinen SL. Screening for BRCA1, BRCA2, CHEK2, PALB2, BRIP1, RAD50, and CDH1 mutations in highrisk Finnish BRCA1/2-founder mutation-negative breast and/or ovarian cancer individuals. Breast Cancer Res. 2011;13(1):R20.

53. Antonucci I, Provenzano M, Sorino L, Rodrigues M, Palka G, Stuppia L. A new case of "de novo" BRCA1 mutation in a patient with early-onset breast cancer. Clin Case Rep. 2017:5(3):238-40.

54. Caux-Moncoutier V, Pagès-Berhouet $S$, Michaux D, Asselain B, Castéra L, De Pauw A, Buecher B, Gauthier-Villars M, Stoppa-Lyonnet D, Houdayer C. Impact of BRCA1 and BRCA2 variants on splicing: clues from an allelic imbalance study. Eur J Hum Genet. 2009;17(11):1471-80.

55. Cherbal F, Bakour R, Adane S, Boualga K, Benais-Pont G. Maillet P; BRCA1 and BRCA2 germline mutations screening in Algerian breast/ovarian cancer families. Dis Markers. 2010;28(6):377-84. 
56. Tavtigian SV, Simard J, Rommens J, Couch F, Shattuck-Eidens D, Neuhausen S, Merajver S, Thorlacius S, Offit K, Stoppa-Lyonnet D, Belanger C, Bell R, Berry S, Bogden R, Chen Q, Davis T, Dumont M, Frye C, Hattier T, Jammulapati S, Janecki T, Jiang P, Kehrer R, Leblanc JF, Mitchell JT, McArthur-Morrison J, Nguyen K, Peng Y, Samson C, Schroeder M, Snyder SC, Steele L, Stringfellow M, Stroup C, Swedlund B, Swense J, Teng D, Thomas A, Tran T, Tranchant M, Weaver-Feldhaus J, Wong AK, Shizuya H, Eyfjord JE, Cannon-Albright L, Tranchant M, Labrie F, Skolnick MH, Weber B, Kamb A, Goldgar DE. The complete BRCA2 gene and mutations in chromosome 13q-linked kindreds. Nat Genet. 1996;12(3):333-7.

57. Levine DA, Argenta PA, Yee CJ, Marshall DS, Olvera N, Bogomolniy F, Rahaman JA, Robson ME, Offit K, Barakat RR, Soslow RA, Boyd J. Fallopian tube and primary peritoneal carcinomas associated with BRCA mutations. JCO. 2003;21(22):4222-7.

58. Graeser MK, Engel C, Rhiem K, Gadzicki D, Bick U, Kast K, Froster UG, Schlehe B, Bechtold A, Arnold N, Preisler-Adams S, Nestle-Kraemling C, Zaino M, Loeffler M, Kiechle M, Meindl A, Varga D, Schmutzler RK. Contralateral breast cancer risk in BRCA1 and BRCA2 mutation carriers. JCO. 2009;27(35):5887-92.

59. Lecarpentier J, Noguès $C$, Mouret-Fourme E, Gauthier-Villars M, Lasset C, Fricker JP, Caron O, Stoppa-Lyonnet D. Berthet P, et alVariation in breast cancer risk associated with factors related to pregnancies according to truncating mutation location, in the French national BRCA1 and BRCA2 mutations carrier cohort (GENEPSO). Breast Cancer Res. 2012;14(4):R99.

60. Sugano K, Nakamura S, Ando J, Takayama S, Kamata H, Sekiguchi I, Ubukata M, Kodama T, Arai M, Kasumi F, Hirai Y, Ikeda T, et al. Cross-sectional analysis of germline BRCA1 and BRCA2 mutations in Japanese patients suspected to have hereditary breast/ovarian cancer. Cancer Sci. 2008;99(10):1967-76.

61. Tea M-KM, Kroiss R, Muhr D, Fuerhauser-Rappaport C, Oefner P, Wagner TM, Singer CF. Central European BRCA2 mutation carriers: birth cohort status correlates with onset of breast Cancer. Maturitas. 2014;77(1):68-72.

62. Heramb C, Wangensteen T, Grindedal EM, Ariansen SL, Lothe S, Heimdal KR, Mæhle L. BRCA1 and BRCA2 Mutation Spectrum - An Update on Mutation Distribution in a Large Cancer Genetics Clinic in Norway. Hered Cancer Clin Pract. 2018;16:3.

63. Caleca L, Catucci I, Figlioli G, De Cecco L, Pesaran T, Ward M, Volorio S, Falanga A, Marchetti M, lascone M, Tondini C, Zambelli A, Azzollini J, Manoukian S, Radice P, Peterlongo P. Two Missense Variants Detected in Breast Cancer Probands Preventing BRCA2-PALB2 Protein Interaction. Front Oncol. 2018;8:480

64. Germani A, Libi F, Maggi S, Stanzani G, Lombardi A, Pellegrini P, Mattei M, De Marchis L. Claudio Amanti, et al; rapid detection of copy number variations and point mutations in BRCA1/2 genes using a single workflow by ion semiconductor sequencing pipeline. Oncotarget. 2018; 9(72):33648-55

65. Walsh T, Casadei S, Coats KH, Swisher E, Stray SM, Higgins J, Roach KC, Jessica Mandell MS, Lee MK, Ciernikova S, Foretova L, Soucek P, King M-C. Spectrum of Mutations in BRCA1, BRCA2, CHEK2, and TP53 in Families at High Risk of Breast Cancer. JAMA. 2006;295(12):1379-88.

66. Cao W-M, Zheng Y-B, Gao Y, Ding X-W, Sun Y, Huang Y, Lou C-J, Pan Z-W, Peng G, Wang $X-J$. Comprehensive mutation detection of BRCA1/2 genes reveals large genomic rearrangements contribute to hereditary breast and ovarian cancer in Chinese women. BMC Cancer. 2019;19:551.

67. Foulkes WD, Smith IE, Reis-Filho JS. Triple-negative breast cancer. N Engl J Med. 2010;363(20):1938-48

68. Lund MJ, Trivers KF, Porter PL, et al. Race and triple negative threats to breast cancer survival: a population-based study in Atlanta, GA. Breast Cancer Res Treat. 2009;113(2):357-70.

69. De Silva S, Hemamala K, Tennekoon, Hamilton E, Karunanayake. Overview of the genetic basis toward early detection of breast cancer. Breast Cancer. 2019;11:71-80 2019:11 71-80.

\section{Publisher's Note}

Springer Nature remains neutral with regard to jurisdictional claims in published maps and institutional affiliations.

Ready to submit your research? Choose BMC and benefit from:
- fast, convenient online submission
- thorough peer review by experienced researchers in your field
- rapid publication on acceptance
- support for research data, including large and complex data types
- gold Open Access which fosters wider collaboration and increased citations
- maximum visibility for your research: over 100M website views per year
At BMC, research is always in progress.
Learn more biomedcentral.com/submissions

